\title{
Perceptions and practices of mosquito- borne diseases in Alabama - is concern where it should be?
}

\author{
Wayde Morse $^{1^{*}} \mathbb{D}$, Katie Izenour ${ }^{2}$, Benjamin McKenzie ${ }^{1}$, Sarah Lessard ${ }^{1}$ and Sarah Zohdy ${ }^{1,2}$
}

\begin{abstract}
Background: The Gulf Coast of the United States is home to mosquito vectors that may spread disease causing pathogens, and environmental conditions that are ideal for the sustained transmission of mosquito-borne pathogens. Understanding public perceptions of mosquito-borne diseases and mosquito prevention strategies is critical for the development of effective vector control strategies and public health interventions. Here, we present a survey conducted in Mobile, Alabama along the Gulf Coast to better understand public perceptions of mosquitoborne diseases, mosquito control activities, and potential risk factors.

Methods: Using Knowledge, Attitude, and Practice (KAPs) assessments, we surveyed populations living in 12 zip codes in Mobile, Alabama using a 7-point Likert scale and frequency assessments. Survey participants were asked about vector control efforts, knowledge of mosquito-borne diseases, and understanding of mosquito ecology and breeding habitats.
\end{abstract}

Results: One hundred twenty-six surveys were completed in Mobile, Alabama, revealing that $73 \%$ of participants reported being bitten by a mosquito in the last 30 days and mosquitoes were frequently seen in their homes. Ninety-four percent of respondents had heard of Zika Virus at the time of the survey, and respondents reported being least familiar with dengue virus and chikungunya virus.

Conclusions: Chikungunya virus, dengue virus, malaria, West Nile virus, and Zika virus have been documented in the Gulf Coast of the United States. The mosquitoes which vector all of these diseases are presently in the Gulf Coast meaning all five diseases pose a potential risk to human health. The results of this survey emphasize knowledge gaps that public health officials can address to empower the population to reduce their risk of these mosquito-borne diseases. Each species of mosquito has specific preferences for breeding and feeding and there is no one size fits all prevention approach, educating people on the need for a variety of approaches in order to address all species will further empower them to control mosquitoes where they live and further reduce their risk of disease.

Keywords: KAP survey, Zika, Chikungunya, West Nile virus, Malaria, Vector control, Mosquito ecology

\footnotetext{
* Correspondence: morsewc@auburn.edu

${ }^{1}$ Auburn University School of Forestry and Wildlife Sciences, 602 Duncan Dr,

Auburn, AL 36849, USA

Full list of author information is available at the end of the article
}

(c) The Author(s). 2019 Open Access This article is distributed under the terms of the Creative Commons Attribution 4.0 International License (http://creativecommons.org/licenses/by/4.0/), which permits unrestricted use, distribution, and reproduction in any medium, provided you give appropriate credit to the original author(s) and the source, provide a link to the Creative Commons license, and indicate if changes were made. The Creative Commons Public Domain Dedication waiver (http://creativecommons.org/publicdomain/zero/1.0/) applies to the data made available in this article, unless otherwise stated. 


\section{Background}

The sub-tropical climate of the US Gulf Coast, as well as an abundance of habitat for Aedes, Culex and Anopheles mosquitoes and the proximity of trade and travel hubs, put the Gulf Coast at risk for the establishment or re-establishment of mosquito-borne pathogens in the US [1]. Until the implementation of vigorous vector control efforts in the mid-twentieth century, the Gulf Coast experienced regular outbreaks of malaria and yellow fever [2, $3]$. In more recent years, the Gulf Coast has been under threat of endemic transmission of mosquito-borne RNA viruses such as West Nile virus (WNV), dengue fever virus (DENV), chikungunya virus (CHIKV) and Zika virus (ZIKV) [4-7]. Vector control efforts have been stymied by the growing prevalence of insecticide resistance among many mosquito taxa as well as funding cuts due to a public perception that mosquito-borne pathogens no longer present much threat in the US $[8,9]$. The potential for emergence and re-emergence of mosquito-borne diseases in this geographic region points to a growing need to develop strategies to combat the transmission of mosquito-borne pathogens.

A few mosquito-borne pathogens that pose potential threats in the region due to the distribution of their mosquito vectors include CHIKV, DENV [10], malaria (MAL) [11], WNV $[12,13]$ and ZIKV. All of these pathogens have been detected in Gulf Coast states in recent years, though many of these cases have been considered to be imported cases, not acquired locally (Table 1). WNV, which is transmitted by Culex mosquitoes, is the most prevalent mosquito-borne disease in the US, with an average of 2,000 and up to 9,800 cases per year (between 1999 and 2017) [16]. Symptoms range from mild febrile illness, to severe encephalopathy to death [17]. Meanwhile, ZIKV, DENV and CHIKV, all transmitted by Aedes mosquitoes, have recently emerged and re-emerged in Gulf States, mostly in travel-related cases, but achieving autochthonous transmission in Florida $[5,6,18]$. Historically, MAL was prevalent in the southeastern US, with parasites transmitted by Anopheles mosquitoes. Malaria symptoms typically include cyclical fevers, anemia, and fatigue and are often fatal in pregnant women and children under the age of 5 [19]. Following massive mosquito control efforts in the US, including the use of DDT as pesticide, MAL was eliminated from the region [2]. While MAL transmission is not endemic to the southeastern US, there are still a handful of reported human cases annually, typically attributed to travel. A well-known mosquito vector of MAL (An. quadrumaculatus) remains around the US Gulf Coast and is a very common nocturnal mosquito. It is important to note that these pathogens are transmitted by different genera of mosquitoes, each with different ecologies and thus requiring different strategies for vector control (Table 2).

While many public health strategies exist to combat the spread of mosquito-borne pathogens, including insecticide use, gene drives and reduction of breeding habitat, none of these methods is entirely effective on its own and all of these methods benefit from the aid of public education [20-22]. A populace educated in the transmission cycles of mosquito-borne pathogens, as well as common steps taken to interrupt this cycle, can be invaluable to public health efforts $[20,21]$. Thus, an informed private citizenry could be an important tool for vector control strategies in the region.

To gauge residents' current level of understanding surrounding mosquito-borne pathogens present in the Gulf Region, we conducted a pilot survey among residents of the Mobile Bay area in the Gulf, where Ae. aegypti mosquitoes, which are responsible for mosquito borne diseases like CHIKV, ZIKV, and DENV have recently been detected following a 26-year absence [1]. Through this pilot survey, we asked residents of Alabama's Mobile Bay area about their practices to reduce the number of mosquitoes, level of knowledge, degree of concern and perceptions of seriousness about five mosquito-borne diseases, preferred modality for receiving information and the perceived impact their mosquito prevention measures have on their homes and neighborhood. This information is the core of planning and targeting public health and community prevention and outreach programs. We hypothesize that residents of the Mobile area will report being bitten frequently by mosquitoes. We also hypothesize that Mobile area citizens will report high levels of knowledge and concern about ZIKV and less knowledge and concern about the other diseases that are of equal or greater importance in the area.

Table 1 Distribution and risk of mosquito-borne diseases that have been reported along the Gulf Coast and Alabama [5, 14, 15]

\begin{tabular}{llll}
\hline Disease & Reported in Alabama & Reported along Gulf Coast & *Total No. Cases in Alabama 2013-2018 \\
\hline chikungunya virus & Imported cases & Locally acquired & 22 \\
dengue virus & Imported cases & Locally acquired & 17 \\
malaria & Imported cases & Imported cases & 53 \\
West Nile virus & Locally acquired & Locally acquired & 128 \\
zika virus & Imported cases & Locally acquired and imported & 49 \\
\hline
\end{tabular}


Table 2 Important characteristics of mosquito species found in Alabama

\begin{tabular}{|c|c|c|c|c|c|}
\hline Genus & Species & Vectors of Disease & $\begin{array}{l}\text { Active } \\
\text { period }\end{array}$ & Breeding & Resilience \\
\hline Aedes & aegypti albopictus & $\begin{array}{l}\text { Zika virus, dengue fever virus, } \\
\text { chikungunya virus }\end{array}$ & Daytime & Tires, streams, puddles & $\begin{array}{l}\text { Eggs can survive without water } \\
6 \text { months }\end{array}$ \\
\hline Anopheles & quadrimaculatis & Malaria & Nighttime & Agricultural fields & Eggs require water for survival \\
\hline Culex & $\begin{array}{l}\text { pipiens tarsalis } \\
\text { quinquefasciatus }\end{array}$ & West Nile virus & & $\begin{array}{l}\text { Wastewater, sewage, } \\
\text { bird baths, flower pots }\end{array}$ & Eggs require water for survival \\
\hline
\end{tabular}

\section{Methods}

\section{Survey and sample selection}

A fifty-question paper survey developed for this project was mailed to a random sample of 1,000 residents in the urban center of Mobile Bay along Alabama's Gulf Coast (Additional file 1). Surveys were sent out in July and August 2016 along with two follow-up reminders; a post card and a letter spaced two weeks apart. Best practices in survey design and development were followed [23]. The survey asked questions about the participant's: demographics, household information, mosquito avoidance behavior measures, general knowledge, level of concern, and perceptions of the seriousness of several mosquitoborne diseases, and responsibility for mosquito control measures.

All five diseases included in this pilot survey have been documented in humans in the United States, and in the case of CHIKV, DENV, WNV and ZIKV, domestically acquired specifically in Alabama (Table 1).

Surveys were returned to Auburn University's School of Forestry and Wildlife Services and entered into a database for review and further analysis. Knowledge, concern and seriousness questions used 7-point Likert scales while avoidance behavior utilized frequency measures. Analysis is primarily descriptive. The output for this paper was generated using SAS 9.4, Copyright $\odot$ [2002-2012] SAS Institute Inc. Visualizations were created using Microsoft Excel.

\section{Results}

A total of 126 usable surveys were returned and are included in this analysis for a response rate of $15 \%$ when undeliverable surveys were deducted. Participants are largely representative of the underlying population demographics of their geographic area. Referring to the Census Quick Facts, July 1, 2017 population estimates [24] for Mobile Alabama. The survey participant population is slightly older than the census population. Given the similarity to the census demographic figures and budget constraints further non-response bias checks were not conducted. On average, the number of household occupants was 2.4 and $85 \%$ indicated they owned their home.

\section{Mosquito risk}

At the time of survey completion, $73 \%$ of participants reported being bitten by a mosquito in the last 30 days. Participants were asked to rate their perceptions of the level of mosquito density near their home during the last month on a scale from very low [1], to moderate [4], to very high [7]. Approximately $18 \%$ reported the two lowest categories combined very low to low density, 33\% reported the middle moderate and $26 \%$ reported the two highest categories combined high to very high density (Fig. 1). Respondents were also asked to rate the frequency of seeing mosquitos in their home on a 7 point scale from almost never (33\%), up to a few times a month $(17 \%$ \& $22 \%)$, up to a few times a week ( $8 \%$ \& $12 \%)$, up to every day ( $2 \%$ \& 6\%) (Fig. 1). More than two-thirds $(67 \%)$ of participants reported having screens on windows they open at their home and about three quarters (74\%) reported having an open deck or unscreened porch at their home.

Assessing type and frequency of outdoor activities is informative in estimating someone's risk of encountering a mosquito. We provide a breakdown of the frequency participants indicated doing various outdoor activities during the months, May-August (Table 3). On average, walking, relaxing and cooking outdoors were the most common outdoor summer activities. Relaxing (20\%) and walking outdoors (31\%) were the most frequently reported activities that participants reported doing outdoors almost everyday.

\section{Mosquito-borne disease knowledge, concern and perceptions of seriousness}

Almost all participants, 94\% reported hearing of ZIKV before receiving this survey. Participants were asked the level of their current knowledge regarding the five mosquito transmitted diseases. DENV and CHIKV were the two mosquito-borne diseases participants reported being the least familiar with each rating $88 \%$ less than knowledgeable (Table 4). MAL and WNV had $50 \%$ or more reporting that they were less than knowledgeable with only ZIKV reported at 52\% knowledgeable or above. Participant knowledge of mosquito breeding preferences was high regarding some items (standing water (98\%), bird baths $(76 \%)$, old tires $(71 \%)$ ) but decreased significantly 


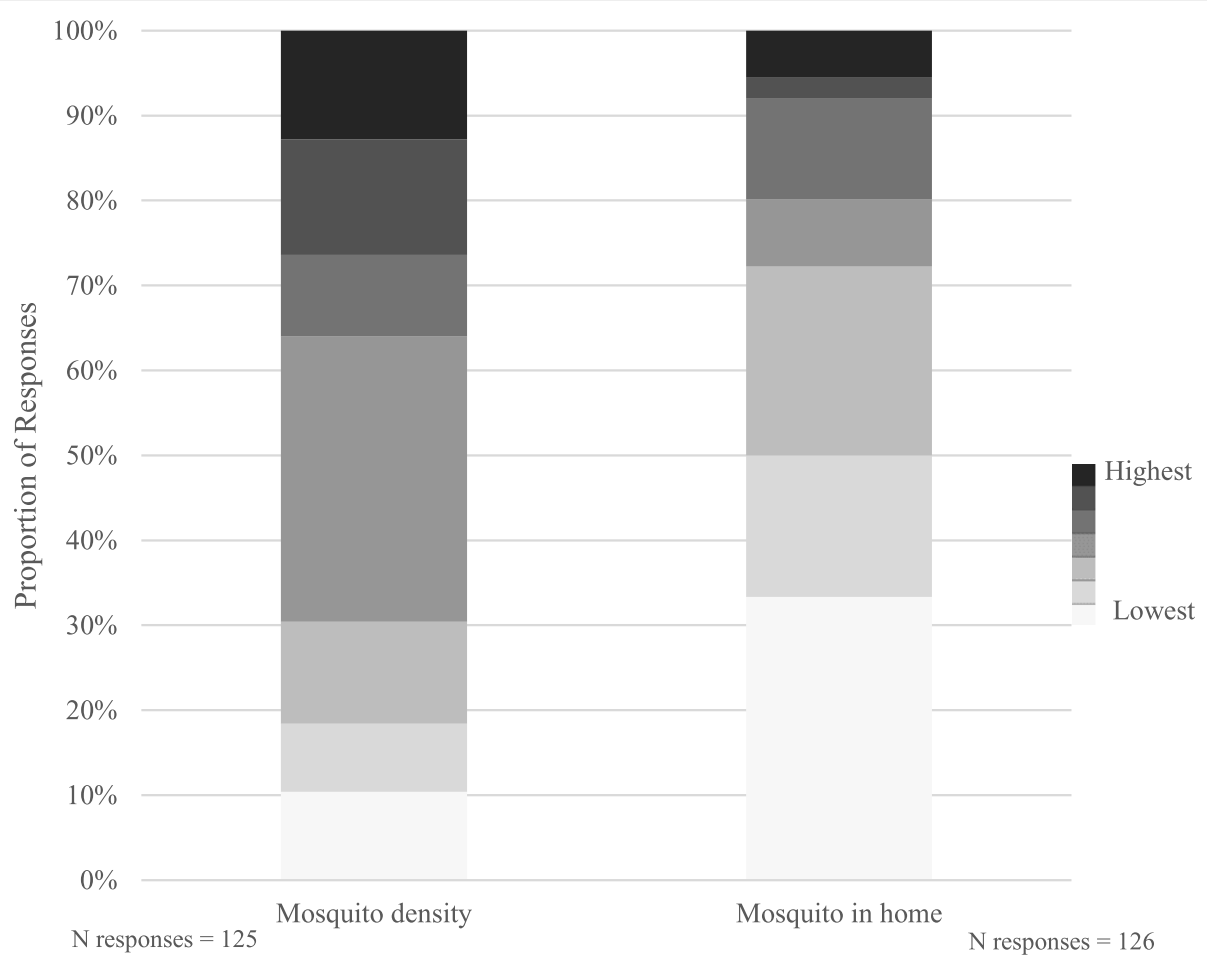

Fig. 1 Participant's reported mosquito density around home and frequency mosquito in their home, last 30 days

for some other common breeding areas (empty containers (51\%) and rain gutters (61\%).

Concern expressed about potentially contracting one of the diseases had interesting dispersions. Almost half or more of all respondents indicated they were not concerned at all or minimally concerned about any of the diseases (47-66\%). About a fifth to a quarter (19-28\%) registered that they were concerned about they or a family member would contract any of the diseases. A

Table 3 Frequency in percentage of outdoor activities during summer months (May-August)

\begin{tabular}{lllll}
\hline & Never & $\begin{array}{l}\text { A few times a } \\
\text { month or less }\end{array}$ & $\begin{array}{l}\text { A few times } \\
\text { a week }\end{array}$ & $\begin{array}{l}\text { Almost } \\
\text { everyday }\end{array}$ \\
\hline Bird watching & 89 & 9 & 1 & 1 \\
Cooking outdoors & 23 & 49 & 20 & 8 \\
Fishing & 58 & 35 & 7 & 0 \\
Gardening & 29 & 35 & 23 & 13 \\
Hiking in woods & 81 & 16 & 3 & 0 \\
Horseback riding & 97 & 3 & 1 & 0 \\
Hunting & 89 & 11 & 0 & 0 \\
Relaxing & 13 & 32 & 34 & 20 \\
Running & 72 & 19 & 5 & 4 \\
Outdoor sports & 64 & 28 & 6 & 3 \\
Walking & 8 & 29 & 31 & 31 \\
Other outdoor activities & 23 & 50 & 19 & 8 \\
\hline
\end{tabular}

small but significant percentage of participants (13-21\%) reported being extremely concerned about contracting any of the diseases (Table 4). Participants indicated they were most concerned about contracting ZKV (21\%) followed closely by WNV (18\%). Nearly two-thirds of respondents (65-66\%) were less than concerned about CHIKV, DENV and MAL.

Participants were asked how serious they thought an infection from each of the five diseases of interest would be should they or a family member become infected. Participants overwhelmingly reported (79-90\%) that they thought all the diseases were serious to extremely serious if infected (Table 4). Nearly four in ten respondents felt that each of the diseases were extremely serious for their health.

\section{Mosquito avoidance}

Two questions asking about participant's activities to reduce mosquitoes around their home and prevent a mosquito bites showed participants are very knowledgeable about a variety of effective mosquito reduction and avoidance practices (Table 5). Dumping water from containers (54\%) and flowerpots (58\%) or treating bird baths (28\%), checking boats or other large items (28\%) and dumping water from kid's toys $(26 \%)$ were the most frequently reported activities occurring 'a few times a week' or more. The least frequently reported activities were checking rain 
Table 4 Level of knowledge, concern, and seriousness of each disease in percentages

\begin{tabular}{|c|c|c|c|c|c|c|}
\hline \multirow[t]{6}{*}{$\begin{array}{l}\text { Current knowledge of } \\
\text { the following diseases }\end{array}$} & & $\begin{array}{l}\text { Not knowledgeable } \\
\text { at all }\end{array}$ & $\begin{array}{l}\text { Somewhat } \\
\text { knowledgeable }\end{array}$ & Knowledgeable & Very knowledgeable & $\begin{array}{l}\text { Extremely } \\
\text { knowledgeable }\end{array}$ \\
\hline & $\begin{array}{l}\text { chikungunya } \\
\text { virus }\end{array}$ & 72 & 16 & 7 & 0 & 5 \\
\hline & dengue virus & 66 & 22 & 5 & 2 & 4 \\
\hline & malaria & 16 & 42 & 26 & 8 & 7 \\
\hline & $\begin{array}{l}\text { West Nile } \\
\text { virus }\end{array}$ & 14 & 36 & 31 & 8 & 11 \\
\hline & Zika virus & 10 & 39 & 33 & 7 & 12 \\
\hline \multirow[t]{6}{*}{$\begin{array}{l}\text { Concern you or a family } \\
\text { member will contract disease }\end{array}$} & & Not Concerned & $\begin{array}{l}\text { Minimally } \\
\text { concerned }\end{array}$ & Concerned & $\begin{array}{l}\text { More than concerned, but } \\
\text { not extremely }\end{array}$ & $\begin{array}{l}\text { Extremely } \\
\text { Concerned }\end{array}$ \\
\hline & $\begin{array}{l}\text { chikungunya } \\
\text { virus }\end{array}$ & 35 & 30 & 20 & 0 & 15 \\
\hline & dengue virus & 36 & 29 & 21 & 0 & 15 \\
\hline & malaria & 34 & 32 & 19 & 2 & 13 \\
\hline & $\begin{array}{l}\text { West Nile } \\
\text { virus }\end{array}$ & 16 & 38 & 24 & 3 & 18 \\
\hline & Zika virus & 17 & 30 & 28 & 4 & 21 \\
\hline \multirow[t]{6}{*}{$\begin{array}{l}\text { How serious do you feel an } \\
\text { infection would be? }\end{array}$} & & Not serious & $\begin{array}{l}\text { Minimally } \\
\text { serious }\end{array}$ & Serious & $\begin{array}{l}\text { More than serious, but not } \\
\text { extremely serious }\end{array}$ & $\begin{array}{l}\text { Extremely } \\
\text { serious }\end{array}$ \\
\hline & $\begin{array}{l}\text { chikungunya } \\
\text { virus }\end{array}$ & 3 & 13 & 39 & 10 & 38 \\
\hline & dengue virus & 4 & 10 & 36 & 12 & 38 \\
\hline & malaria & 4 & 8 & 34 & 14 & 42 \\
\hline & $\begin{array}{l}\text { West Nile } \\
\text { virus }\end{array}$ & 3 & 11 & 30 & 17 & 40 \\
\hline & Zika virus & 4 & 16 & 31 & 8 & 42 \\
\hline
\end{tabular}

gutters (71\%) and using a bug lamp or zapper (77\%) occasionally or never doing these activities.

On average participants reported the most common activities they did to avoid a mosquito bite were 'Avoiding areas where mosquitoes are present' (50\%) and 'Minimize time outside in the evening'(48\%) at least a few times a week. Highly effective mosquito bite avoidance activities like 'wearing a long sleeve shirt (77\%) or using a repellent with DEET (75\%) were reported as being utilized less than a few times a month.

\section{Beliefs and impact}

Participants are split about the impact their actions to control mosquitoes have on both their own home and their surrounding neighborhood. A little more than half of the responses (53\%) indicated that people perceive their actions to have 'some impact' on the mosquito population around both their homes or neighborhoods. There is a small group or participants who perceive their actions to have a very little (14\%) and another third (33\%) who perceive a very significant impact around their homes and neighborhoods. Additionally, participants believe they (77\%) along with their local government (69\%) and health department (78\%) are responsible for mosquito control efforts.

\section{Discussion}

In this study, we conducted a survey to evaluate citizen knowledge, attitudes, and practices as they relate to mosquitoes and mosquito-borne diseases found in the southeastern United States.

\section{Mosquito risk}

Our results indicate moderate densities of mosquitoes near homes in Mobile, as well as a high frequency of encounters with mosquitoes in residents' homes (Fig. 1). The prevalence of mosquitoes in residential areas suggests that more emphasis on vector control is necessary to prevent risk of exposure to mosquito-borne pathogens. However, factors such as varying ecologies and increasing prevalence of insecticide resistance among mosquitoes make the task of vector control all the more daunting $[9,22]$.

Mosquitoes from the three main genera of public health concern, Aedes, Anopheles and Culex, have different ecologies and life-history strategies, complicating vector control strategies that target breeding sites or 
Table 5 Mosquito avoidance and reduction practices in percentage

\begin{tabular}{|c|c|c|c|c|c|}
\hline & & $\begin{array}{l}\text { Never/ } \\
\text { occasionally }\end{array}$ & $\begin{array}{l}\text { A few times } \\
\text { a month }\end{array}$ & $\begin{array}{l}\text { A few times } \\
\text { a week }\end{array}$ & Everyday \\
\hline \multirow[t]{9}{*}{$\begin{array}{l}\text { Activities to reduce mosquitoes around } \\
\text { home }\end{array}$} & $\begin{array}{l}\text { Replaced or treated water in a bird bath or } \\
\text { fountain }\end{array}$ & 56 & 16 & 18 & 10 \\
\hline & Used a bug lamp/zapper & 77 & 7 & 8 & 7 \\
\hline & $\begin{array}{l}\text { Checked boats and other large items for } \\
\text { standing water }\end{array}$ & 52 & 20 & 17 & 11 \\
\hline & Checked and cleaned gutters & 71 & 17 & 9 & 4 \\
\hline & Cleared back overgrown shrubs/trees & 30 & 49 & 18 & 3 \\
\hline & $\begin{array}{l}\text { Dumped water from other containers } \\
\text { that held water }\end{array}$ & 17 & 29 & 42 & 12 \\
\hline & Dumped standing water from flower pots & 14 & 28 & 41 & 17 \\
\hline & Dumped water from kid's toys & 58 & 19 & 13 & 10 \\
\hline & Mowed lawn & 6 & 72 & 19 & 3 \\
\hline \multirow[t]{9}{*}{ Activities to prevent a mosquito bite } & Wear a long sleeve shirt & 52 & 25 & 16 & 7 \\
\hline & Wear long pants & 34 & 23 & 20 & 23 \\
\hline & Use a repellant without DEET & 73 & 15 & 10 & 2 \\
\hline & Use a repellant with DEET & 49 & 26 & 20 & 6 \\
\hline & Minimize time outside in the morning & 43 & 19 & 18 & 20 \\
\hline & Minimize time outside in the evening & 35 & 21 & 19 & 26 \\
\hline & Avoid areas where mosquitoes are present & 34 & 17 & 18 & 32 \\
\hline & Burn Citronella candles & 69 & 15 & 10 & 6 \\
\hline & Other & 47 & 32 & 11 & 11 \\
\hline
\end{tabular}

temporal avoidance of mosquitoes. Mosquitoes of the Anopheles quadrumaculatus complex, which are thought to be the only mosquitoes in the US capable of transmitting malaria, tend to breed in swampy habitats which are quite common in the Mobile Bay area [25]. Culex mosquitoes, which are the primary vectors of $\mathrm{WNV}$, also often breed in man-made containers, though they will also breed in tree holes, rock pools, and sewage overflows [26]. Finally, the mosquitoes Aedes aegypti, Aedes albopictus and Aedes japonicus, which vector a suite of viruses and parasites including CHIKV, DENV, WNV and ZIKV, are diurnal feeders which prefer to breed in man-made containers, such as tires and flower pots [27-29]. Furthermore, Aedes mosquitoes tend to bite during the day, while Culex and Anopheles mosquitoes feed at dawn, dusk and nighttime [26]. This variety of ecologies necessitates a multitude of coordinated approaches to reduce mosquito vector populations. Improving mosquito burden around resident's homes can be accomplished by encouraging residents to us unimpaired screens over windows and porches as well as clearing areas where mosquitoes prefer to live and breed.

The process of vector control is further complicated by the growing prevalence of insecticide resistance among Aedes, Anopheles and Culex mosquitoes [30-32]. Long-term and improper use of insecticides such as pyrethroids by commercial and governmental entities have led to the development of so called knockdown resistance (KDR) genes among mosquito populations around the world $[30,33]$. While there are many efforts to create new insecticides to replace those to which the mosquitoes have adapted, future vector control strategies would be wise not to rely too heavily on insecticide use [22]. Instead, future mosquito control programs should integrate targeted insecticide use and reduction of mosquito habitat with public education initiatives [20].

\section{Mosquito-borne disease knowledge, concern and perceptions of seriousness}

The results of our survey suggest that Mobile Bay area residents consider themselves more knowledgeable and more concerned about ZIKV and WNV than CHIKV or DENV. This perception may have been colored by the timing of the survey, which was released at the tail end of the 2014-2016 ZIKV epidemic in the Americas. ZIKV was often in the news at the time, the news was likely the source of residents' knowledge/concern. This is supported by a comparatively high level of public knowledge/concern surrounding WNV, another virus that has appeared in the news much in recent history. While MAL and DENV are very rare still, CHIKV is relatively common in the Mobile area [14]. The fact that there are significant numbers in the extreme ends of the scale, 'Not concerned' at all and the 'Extremely concerned', 
indicates that more information is needed on the likelihood of exposure to these diseases. DENV and CHIKV, while commonly reported in US Gulf States such as Florida and Texas, are not as widely discussed in the media and thus the general public is not as educated about the threats they pose. Furthermore, knowledge regarding MAL might be due to its larger global discussion [34]. One potential reason for lack of concern may be because CHIKV and DENV like other flaviviruses (including ZIKV and WNV) do not always present as severe illness or may just feel flu-ish and not seek medical care [35]. In the majority of cases (up to $80 \%$ for ZIKV) infected individuals are asymptomatic [36]. The lack of physical symptoms may allow these viruses to go largely undetected.

The high level of knowledge about mosquito breeding preferences, standing water, old tires was also likely due to the local media coverage of the ZIKV epidemic at the time the survey was administered. The reported knowledge of mosquito breeding preferences emphasized many opportunities for improved education and outreach to make residents aware of the importance of a varied vector control approach because of the differences in preference by each mosquito species.

\section{Mosquito avoidance}

The public health campaigns around the ZIKV epidemic were very effective, people did listen and understand the information disseminated by public health authorities and the media. Though the ZIKV epidemic has faded into the background, Gulf Coast and Mobile Bay region remain at threat from mosquito-borne pathogens. The mosquito avoidance activities reported in Table 5 are reflective of a population very aware of strategies to mitigate mosquito bites. This information also shows an opportunity to increase community awareness about the utility of a multi-pronged approach to mosquito avoidance. No single activity will eliminate mosquitoes or prevent bites because of the diversity of mosquito habitat, breeding and active periods.

\section{Beliefs and impacts}

The data collected in this pilot survey shows that participants believe their actions can have an impact on the burden of mosquitoes in and around their homes. This presents an opportunity for public health official to engage with and equip the public with the knowledge and resources to reduce the risk of transmission of mosquito-borne pathogens.

\section{Strengths and limitations}

This study provides data on human behaviors and perceptions of mosquitoes and mosquito-borne pathogens that can help refine and focus public health efforts, vector control efforts and public health educational materials.
This survey was administered at the beginning of the summer and it is possible that residents were out of town when the survey and reminders were sent, limiting participation. This survey was also administered on the heels of the ZIKV outbreak and the intense media coverage at the time possibly skewed resident's typical knowledge of mosquitoes and mosquito-borne disease. The response rate of the survey was limited which may reduce representativeness of the findings. Conducting mosquito trapping and surveillance activities at the residents of the participants would be needed to more strongly correlate disease risk with survey findings. Future work investigating different physiographic regions around the gulf where mosquito presence and disease risk likely to vary will provide more insight into the prevalence of mosquito species in the region.

\section{Conclusion}

The results of this survey show strong evidence that residents of the Mobile Bay area in Alabama are aware of mosquitoes in and around their homes and that they are aware of at least some of the five mosquito-borne diseases included in this survey. Respondents overwhelmingly consider the health impacts from these diseases as serious. However, their self-reported knowledge of the different diseases is variable and their level of concern about they or their family contracting the diseases is bimodal, with some not concerned at all about them while others are extremely concerned. Clearly additional outreach on the different diseases, the likelihood of contraction, and the seriousness to different populations is needed. Participants are willing to take actions to reduce mosquito populations and are willing to behave in ways that reduce their exposure to mosquitos. The participants included in this analysis feel very empowered and responsible for mosquito control in and around their homes and neighborhoods and this presents a prime opportunity for education and outreach efforts. Capitalizing on the knowledge and the mosquito reduction and avoidance activities already being performed can provide opportunity for enhanced education and awareness. Improving education so local resident concern is appropriately placed for the vectors and diseases found in their area will allow residents to strategically engage in mosquito avoidance and reduction activities appropriate for the ecology of the vectors in their area. Outreach activities from the local government and health department who are considered very trustworthy by the respondents to improve education and awareness specific to these diseases and vectors would be an appropriate next step.

The results of this survey can assist in identifying and correcting misconceptions and misinformation about mosquito activity and the effectiveness of interventions and avoidance efforts, will be key for strengthening public health and community outreach activities. 


\section{Additional file}

Additional file 1: Mobile Mosquito Survey Booklet. This file is the questionnaire used for this study. (PDF $277 \mathrm{~kb}$ )

\section{Abbreviations}

CHIKV: Chikungunya virus; DENV: Dengue fever virus; MAL: Malaria; WNV: West Nile virus; ZIKV : Zika virus

\section{Acknowledgements}

Not applicable.

\section{Authors' contributions}

WM designed the study, questionnaire, conducted initial analysis, and was a major contributor in writing the manuscript. Kl conducted the advanced analysis and was a major contributor in writing the manuscript. BM provided background on the specific diseases and mosquito ecology and contributed to writing of the manuscript. SL administered the survey and preformed preliminary analysis. SZ provided information on the presence of diseases and vectors in Alabama, information on specific diseases, and was a major contributor in writing the manuscript. All authors have read and approved the manuscript.

\section{Funding}

This was a self-funded pilot project.

\section{Availability of data and materials}

The datasets used and/or analyzed during the current study are available from the corresponding author on reasonable request.

\section{Ethics approval and consent to participate}

The research with human subjects was approved through the Auburn University Internal Review Board (IRB) Administration Protocol \#16-214 EP 1606. In accordance with the IRB, all respondents were informed in their information letter that their voluntary response to the survey constituted their consent to participate.

\section{Consent for publication}

Not applicable.

\section{Competing interests}

The authors declare that they have no competing interests.

\section{Author details}

${ }^{1}$ Auburn University School of Forestry and Wildlife Sciences, 602 Duncan Dr, Auburn, AL 36849, USA. ${ }^{2}$ Auburn University College of Veterinary Medicine, 166 Greene Hall, Pathobiology Rm 161, Auburn, AL 36849, USA

\section{Received: 21 February 2019 Accepted: 11 July 2019}

Published online: 23 July 2019

\section{References}

1. Zohdy S, Morse WC, Mathias D, Ashby V, Lessard S. Detection of Aedes (Stegomyia) aegypti (Diptera: Culicidae) populations in southern Alabama following a 26-yr absence and public perceptions of the threat of Zika virus. J Med Entomol. 2018:55(5):1319-24.

2. Faust $E$. The history of Malaria in the United States. Am Sci. 1951;39(1):121-30

3. Patterson KD. Yellow fever epidemics and mortality in the United States, 1693-1905. Soc Sci Med (1982). 1992;34(8):855-65.

4. Komar N. West Nile virus: epidemiology and ecology in North America. Adv Virus Res. 2003;61:185-234

5. Kendrick K, Stanek D, Blackmore C. Notes from the field: transmission of chikungunya virus in the continental United States--Florida. 2014 MMWR Morbidity and Mortality Weekly Report. 2014;63(48):1137.

6. Graham AS, Pruszynski CA, Hribar LJ, DeMay DJ, Tambasco AN, Hartley AE, et al. Mosquito-associated dengue virus, Key West, Florida, USA, 2010. Emerg Infect Dis. 2011;17(11):2074-5.

7. Metsky HC, Matranga CB, Wohl S, Schaffner SF, Freije CA, Winnicki SM, et al. Zika virus evolution and spread in the Americas. Nature. 2017;546(7658):411-5
8. Gubler DJ. The global emergence/resurgence of arboviral diseases as public health problems. Arch Med Res. 2002:33(4):330-42

9. Liu N. Insecticide resistance in mosquitoes: impact, mechanisms, and research directions. Annu Rev Entomol. 2015;60:537-59.

10. World Health Organization. Dengue and severe dengue [Webpage]. 2018 [updated 201813 Sept. Available from: http://www.who.int/en/news-room/ fact-sheets/detail/dengue-and-severe-dengue.

11. Mace KE, Arguin PM, Tan KR. Malaria Surveillance - United States, 2015. Morbidity and mortality weekly report Surveillance summaries (Washington, DC : 2002). 2018;67(7):1-28.

12. Centers for Disease Control and Prevention. West Nile virus webpage: Centers for Disease Control; 2018 [updated 201828 Nov. Available from: https://www.cdc.gov/westnile/index.html.

13. Curren EJ, Lehman J, Kolsin J, Walker WL, Martin SW, Staples JE, et al. West Nile virus and other nationally notifiable Arboviral diseases - United States, 2017. MMWR Morb Mortal Wkly Rep. 2018;67(41):1137-42.

14. Centers for Disease Control and Prevention. Arbonet 2018 [Available from: https://wwwn.cdc.gov/arbonet/maps/ADB_Diseases_Map/index.html.

15. Alabama Public Health, Mosquito-Borne Diseases [updated April 23, 2019. Available from: http://www.alabamapublichealth.gov/mosquito/.

16. Centers for Disease Control and Prevention. Final Cumulative Maps and Data | West Nile Virus | CDC 2018 [Available from: https://www.cdc.gov/ westnile/statsmaps/cumMapsData.html.

17. Hubálek Z, Halouzka J. West Nile fever--a reemerging mosquito-borne viral disease in Europe. Emerg Infect Dis. 1999;5(5):643-50.

18. Centers for Disease Control and Prevention. CDC Press Release [Internet] Internet 2016 [Available from: https://www.cdc.gov/media/releases/2016/ p0729-florida-zika-cases.html.

19. Tuteja R. Malaria - an overview. FEBS J. 2007;274(18):4670-9.

20. Abramides GC, Roiz D, Guitart R, Quintana S, Guerrero I, Gimenez N. Effectiveness of a multiple intervention strategy for the control of the tiger mosquito (Aedes albopictus) in Spain. Trans R Soc Trop Med Hyg. 2011;105(5):281-8

21. Espinoza-Gomez F, Hernandez-Suarez CM, Coll-Cardenas R. Educational campaign versus malathion spraying for the control of Aedes aegypti in Colima. Mexico J Epidemiol Comm Health. 2002;56(2):148-52.

22. Robert IR. Pesticides and public health: integrated methods of mosquito management. Emerging Infectious Disease journal. 2001;7(1):17.

23. Dillman DA, Phelps G, Tortora R, Swift K, Kohrell J, Berck J, et al. Response rate and measurement differences in mixed-mode surveys using mail, telephone, interactive voice response (IVR) and the internet. Soc Sci Res. 2009;38(1):1-18

24. United States Census Bureau. Quick Facts Mobile County, Alabama, United States Census Bureau; [updated V 2017. Available from: https://www.census. gov/quickfacts/mobilecountyalabama.

25. Levine RS, Peterson AT, Benedict MQ. Distribution of members of Anopheles quadrimaculatus say s.l. (Diptera: Culicidae) and implications for their roles in Malaria transmission in the United States. J Med Entomol. 2004;41(4):607-13.

26. Andrews JM. The natural history of mosquitoes. Am J Public Health Nations Health. 1949;39(12):1592

27. Christophers R. Aëdes aegypti $(L)$ the yellow fever mosquito: its life history, bionomics and structure: Cambridge University Press; 1960.

28. Estrada-Franco JG, Craig GB Jr. Biology, disease relationships, and control of Aedes albopictus. Biology, Disease Relationships, and Control of Aaedes albopictus. 1995.

29. Kampen $\mathrm{H}$, Werner D. Out of the bush: the Asian bush mosquito Aedes japonicus japonicus (Theobald, 1901) (Diptera, Culicidae) becomes invasive. Parasit Vectors. 2014;7:59.

30. Jones CM, Toe HK, Sanou A, Namountougou M, Hughes A, Diabate A, et al. Additional selection for insecticide resistance in urban malaria vectors: DDT resistance in Anopheles arabiensis from Bobo-Dioulasso, Burkina Faso. PLoS One. 2012:7(9):e45995.

31. Kasai S, Ng LC, Lam-Phua SG, Tang CS, Itokawa K, Komagata O, et al. First detection of a putative knockdown resistance gene in major mosquito vector, Aedes albopictus. Jpn J Infect Dis. 2011:64(3):217-21.

32. Lenormand T, Bourguet D, Guillemaud T, Raymond M. Tracking the evolution of insecticide resistance in the mosquito Culex pipiens. Nature. 1999:400:861 
33. Vontas J, Kioulos E, Pavlidi N, Morou E, della Torre A, Ranson H. Insecticide resistance in the major dengue vectors Aedes albopictus and Aedes aegypti. Pestic Biochem Physiol. 2012;104(2):126-31.

34. Initiative TPSM. The President's Malaria initiative. Internet; 2018.

35. Fernandez-Garcia MD, Mazzon M, Jacobs M, Amara A. Pathogenesis of flavivirus infections: using and abusing the host cell. Cell Host Microbe. 2009;5(4):318-28

36. Lessler J, Chaisson LH, Kucirka LM, Bi Q, Grantz K, Salje H, et al. Assessing the global threat from Zika virus. Science (New York, NY). 2016;353(6300): aaf8160.

\section{Publisher's Note}

Springer Nature remains neutral with regard to jurisdictional claims in published maps and institutional affiliations.

Ready to submit your research? Choose BMC and benefit from:

- fast, convenient online submission

- thorough peer review by experienced researchers in your field

- rapid publication on acceptance

- support for research data, including large and complex data types

- gold Open Access which fosters wider collaboration and increased citations

- maximum visibility for your research: over $100 \mathrm{M}$ website views per year

At $\mathrm{BMC}$, research is always in progress.

Learn more biomedcentral.com/submissions 